\title{
Analysis of the structural behavior of a historical mosque damaged due to an earthquake: Sofular mosque example
}

\author{
Burçin Şenol ŞEKER* and Merve ÖZKAYNAK \\ Department of Architecture, Faculty of Architecture, Amasya University, Amasya, Turkey \\ *Corresponding Author : senol.seker@amasya.edu.tr
}

Submitted :24/02/2020

Revised :08/11/2020

Accepted : 15/12/2020

\begin{abstract}
Since the earliest period of history, many civilizations have ruled our country. Historical structures, which we inherited from these civilizations, should be transferred safely to future generations. For this purpose, it is essential to clearly determine the behavior of these historical structures. In the present study, one of these historical structures, Sofular mosque located in Merzifon, was examined in detail by static and dynamic analysis. In the analysis, the mechanical properties of the material obtained by experimental studies were used. In the static analysis, the mosque was analyzed under its own weight, and it was obtained that the stresses have large values at the supports of the main dome. So, it can be said that the dome has to be supported at these points. The results of the modal analysis show that the mosque has translational displacements with great mass ratios through two orthogonal directions. This shows that the mosque will have out of plane deformation during an earthquake. Also, under the dynamic effects of seismic forces, it was identified that critical out of plane deformations could occur at the upper parts of the eastern and western facades. Also, it is clear that large stress and deformation values could occur at the narthex part. Moreover, it is determined that the dome portion is involved in translational motion and can be damaged during an earthquake.
\end{abstract}

Keywords: Earthquake; Historical building; Sofular mosque; Static; Dynamic analysis.

\section{INTRODUCTION}

Anatolia region, with respect to its history, stands out as quite rich in historical artefacts and ruins. Following the reigns of Rome and Byzantine empires, urban development accelerated after the region became part of the Seljuk and Ottoman Empires. Today there are numerous cultural and historical heritage sites such as mosque, madrassah, kulliye (a multifunctional complex), and cupola, which reflect the style and building material of these periods. It is of great importance to preserve and pass down these historical monuments to the next generations as they reflect the local identity of each city.

Static and dynamic analyses of historical buildings can be conducted via finite element method on computers with certain acknowledgements (Bani-Hani \& Barakat, 2006; Lourenço et al., 1995; Pere Roca et al., 2010). Generally, the modeled buildings, support conditions and material features can be assigned to relevant points and be 
subject to analysis. The purpose of these analyses is to clearly identify the seismic behavior of the building in case of an earthquake. Studies carried out for this purpose bear some differences. Aslan \& Şahin (2016) in their article, have examined the behavior of Sulaymaniyah mosque under the effect of differing earthquakes after creating a 3D model of the building. The dynamic characteristic findings have been compared to the values obtained through experimental methods. The studies have shown the most critical parts of the building and these were analyzed. Alemdar Bayraktar et al. (2019); studied Fatih mosque located in Trabzon concerning windows that were uncovered during restoration and investigated how these windows when open and closed affected the static and seismic behavior. Certain dynamic features of the building were found out through the experiments and finite elements analyses were performed on the improved model. Karaton \& Aksoy (2018) created a 3D model of Diyarbakır Ulu Mosque and performed computerized nonlinear analyses. For the dynamic analyses, three earthquake records were produced and the critical points under strain were identified. In addition, some important strengthening methods were proposed at the end of the study. Orduña et al. (2008) studied two different churches in Colima to investigate damage possibility regarding horizontal and vertical loads. 3D models were created in the form of macro-blocks with respect to damages that occurred in an earthquake in 2003. The models were then scrutinized on a software whose accuracy had been exhibited before. These obtained results have shown that a good prediction related to the collapse mechanism of the building can be made. Paupério et al. (2012); offered the data they obtained in the city of Lorca upon visiting the city two weeks after an earthquake happened there. In the study, they examined the tectonic and seismic structure of the region. Damage levels are evaluated according to an existing evaluation procedure. Gedik \& Celep (2008), created the 3D model of Mehmet Aga Mosque in Istanbul and conducted static and dynamic analyses. After these analyses, they identified the part under stress and analyzed the solution about a support bar in the dome on computer tests. They concluded that this solution can be beneficial in reducing tensile stress.

Historical buildings are a precious legacy that a society has to take over from the previous generation and pass it on to the next generations in a well-preserved condition. As known, Anatolia is a rich geography in terms of its artefacts and buildings which date back thousands of years. Among those historical buildings that form our cultural heritage, mosques are undoubtedly one of the important elements. Some of these mosques have remained standing up until this day despite the external factors such as earthquakes, wars or fires. Of those, earthquake emerges as a significant factor in terms of damage given to buildings since most parts of Turkey are located in high earthquake risk zones.

It is vital to be able to preserve and maintain the historical buildings which serve as important documents reflecting the socio-cultural life of the societies that have existed alongside them, with the architectural culture, building techniques and building materials. In order to carry on this historical legacy, damaged historical buildings need to be restored and strengthened with the aim of allowing public access and use again. Furthermore, through preengineering studies, potential damage zones must be identified, thereby preventing destructive damage from happening in case of a natural disaster.

In this study, the possible damage pattern and distribution have been investigated by studying the seismic performance of Sofular mosque which is located in Merzifon. District of the city of Amasya is situated on North Anatolian Fault line which is the most active fault line in Anatolia. Located in Mid Black Sea Region of Turkey, Amasya stands out as an important city with a historical and cultural richness. After reviewing the earthquake records from the last century that happened in Anatolia region which has numerous active fault lines, it can be seen that these numerous earthquakes have caused damage to historical buildings and traditional housing structures. In this study, in order to determine the structural safety of the mosque, three-dimensional model has been created, material properties have been assigned to the parts and the mosque was analyzed under static and dynamic loads. To determine sufficiency of the parts under static loads and also the parts that could have been damaged during an earthquake is the main goal of this study. 


\section{HISTORICAL AND ARCHITECTURAL CHARACTERISTICS OF SOFULAR MOSQUE}

Located in Sofular Neighborhood, the exact date of construction for this complex including a mosque, a shrine and a water fountain is not clear; however, it is accepted that it was built in the $15^{\text {th }}$ or early $16^{\text {th }}$ century by Abdullah Pasha. The mosque has a square-plan structure with a narthex to the north. On the northern edge of western front of the main building, a minaret is situated adjoint to the main outer wall. On the north-west edge, only the lower part of the cylindrical brick minaret is preserved as in its original form. On the main outer walls, a block with an octagonal plan is situated. The main outer walls of the triptych mosque are made with cut stone material and an alternating pattern was employed by laying three or four rows of brick between each row of stone. The narthex located in the northern part was made in the form of a triple-arched portico. This arch system was built by using two different stones of red and white color together. Three little domes are placed on the portico. The columns in this part all have a capital part and they are connected with wooden stretchers from the support points. The main entrance was built out of marble (Figure 1).

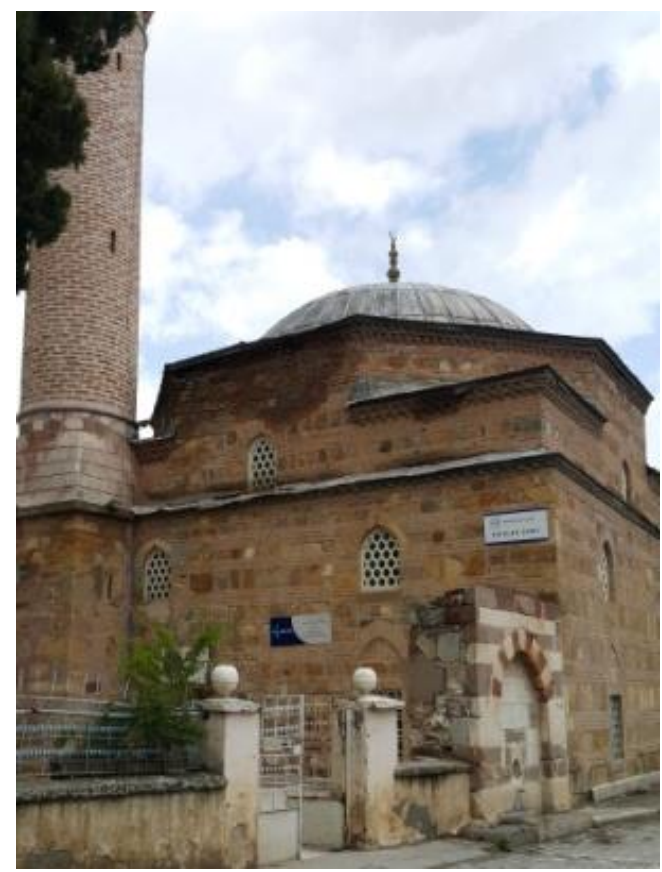

Figure 1. Sofular mosque General View.

The columns at the outer walls, the cincture systems and the narthex are all made of sandstone material; the main and the little domes are built out of bricks. There are five windows located on the outer walls on each of the three walls except for the front entrance door. These windows are located at the lower and upper part of the main outer walls in pairs. The remaining window, however, is located on the octagonal block above the main outer wall. This window is also found on the northern front. Small support cinctures are paved on the windows in order to distribute the load sideways. The windows on the upper part are smaller compared to the ones in the lower part. The main dome is situated on the octagonal block. A squinch is used as a transitional component for dome. According to the accounts of the eye-witnesses which are included in the study of Çerkez (2005), half of the eastern wall and almost half of the main dome of the mosque collapsed in the 1943 earthquake (Figure 2). 


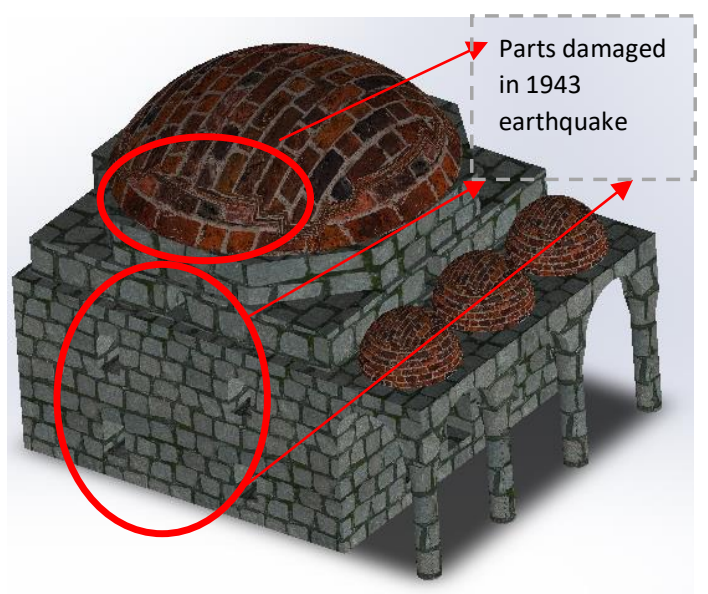

Figure 2. Parts Damaged in 1943 Earthquake.

\section{STRUCTURAL ANALYSIS}

It is quite challenging to scrutinize the structural behavior of historical buildings through analytic methods as well as requiring numerous assumptions (Toker \& Unay, 2004). In addition, calculations on such analyses can generally be made on two dimensions. However, today thanks to technological advancements, analysis of such buildings can be performed on computer software and in 3D. There are quite a number of studies made in this way in the literature. In these studies, the buildings are examined via software using Finite Element Method (FEM), and the parts with a risk of strain and deformation can be identified close to real-life results (Aras et al., 2011; Asteris et al., 2014; Betti \& Vignoli, 2011; P. Roca et al., 2010; Şeker et al., 2013).
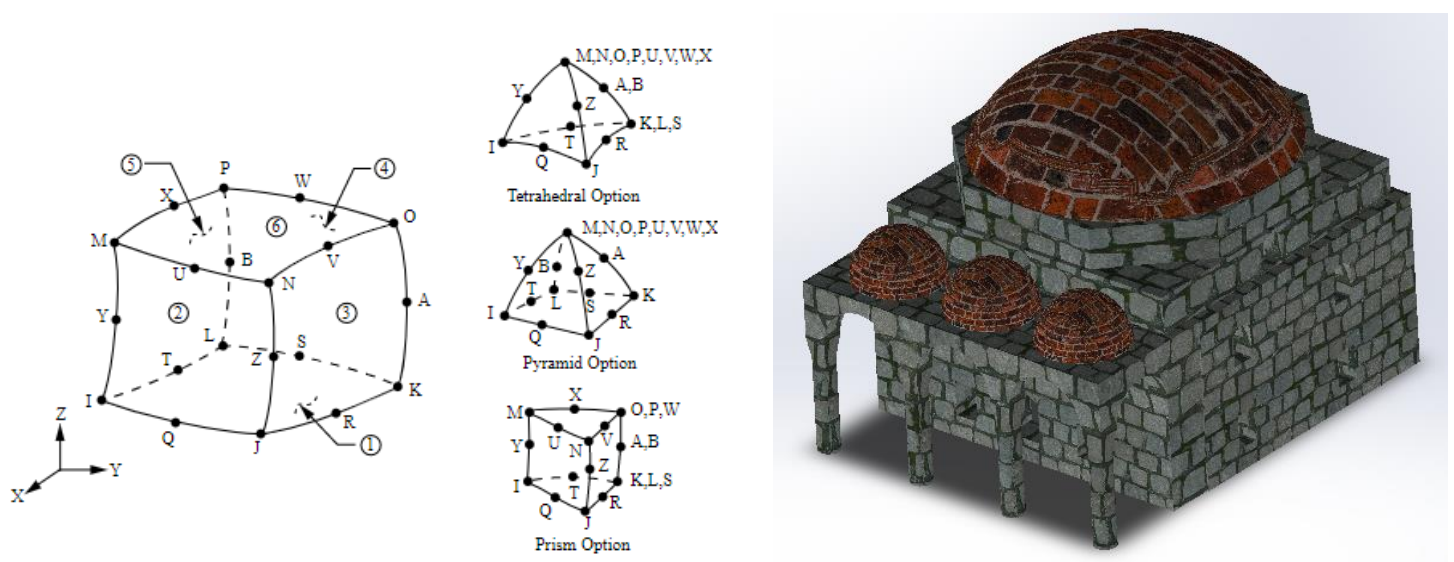

Figure 3. Finite Element and Mosque Model.

The analyses conducted for the mosque studied in this paper are made through ANSYS (2014) software that uses Finite Element Method (FEM). In the scope of this study, the building is considered as a whole with macromodelling technique, and specific mechanic characteristics for each part are assigned to relevant parts corresponding 
to their building material. Within its scope, a 3D model of the mosque was created according to its real dimensions. The geometrical structures of the building, support conditions, and material properties of the relevant parts were assigned to the model. The finite element model consists of 37056 node points and 47204 solid elements in ANSYS Workbench. The Solid 186 elements used for analysis has 20 node points, which each of has three translational freedom. The properties of the Solid 186 (ANSYS (2014)) elements are presented in Fig 3. The minaret was excluded from the analysis in order to examine the deformation and stresses on the main building block. Characteristics of the material to be used in the analysis were identified as a result of the experiments conducted on the materials (Şeker et al., 2014). The main part of the mosque, narthex, and arches were built using cut stones, while the domes were built with bricks. Mechanic and physical features of the materials are shown in Table 1, and the model created for analysis is shown in Figure 3. These analyses conducted on the mosque using the material features are evaluated in two parts as static and dynamic. Because of the size of the mosque model and the high number of nodes, the values obtained from the analyses are presented as a colored propagation in the model.

Table 1. Physical and mechanical features of the materials used in the mosque.

\begin{tabular}{|c|c|c|c|c|c|}
\hline Mosque Part & $\begin{array}{c}\text { Elasticity } \\
\text { Module (Pa) }\end{array}$ & $\begin{array}{c}\text { Poisson } \\
\text { Rate }\end{array}$ & $\begin{array}{c}\text { Specific Bulk } \\
\left.\text { Density (kg/m } \mathbf{m}^{3}\right)\end{array}$ & $\begin{array}{c}\text { Avg. Compressive } \\
\text { Strength (MPa) }\end{array}$ & $\begin{array}{c}\text { Avg. Tensile } \\
\text { Strength (MPa) }\end{array}$ \\
\hline $\begin{array}{c}\text { Main block } \\
\text { (including Outer } \\
\text { walls and } \\
\text { narthex) }\end{array}$ & $1.018 \mathrm{E}+10$ & 0.17 & 2358 & 50.92 & 7.55 \\
\hline Domes & $3.49 \mathrm{E}+9$ & 0.15 & 2037 & 17.49 & 2.69 \\
\hline
\end{tabular}

\section{STATIC ANALYSIS}

In the first part of the study, structural analyses are made according to the fixed loads on the building. As a result of these loadings, the obtained values for strain and deformation are shown in Figure 4 and Figure 5. It can be from in Figure 1 that the principal tensile stress is found to be concentrating on the dome's support points and the peak point of squinches of dome pulley parts. At these points, the stress values reach 0,43 MPa. The forces occurring at the supports of the dome cause the dome to widen sideways under static loads. So, to prevent this, necessary measures need to be taken for these areas during the construction period. It is known that the dome part is built with bricks. Therefore, the principal tensile stress values shown in Figure 4 are lower than the allowable stress which is 2,69 MPa. However, long term loading may cause the supports to be deformed and widen laterally. 


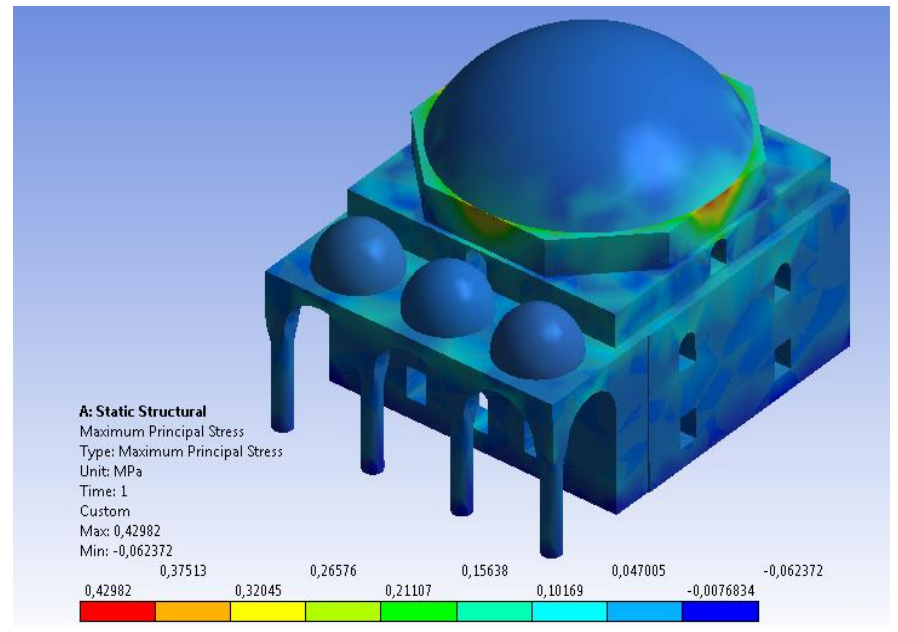

Figure 4. Static Analysis Maximum Principal Stress Values.

To prevent this from happening, A. Bayraktar (2006) emphasized that these parts need to be strengthened with wooden tension elements in mosque building techniques. It is seen that the deformation values in Figure 5 are concentrated around the main dome's peak point. Similarly, A. Bayraktar (2006) also suggested giving prestress to the system by driving nails between the dome brick in mosque building technique. Furthermore, the chandelier hung from the peak point helps with the stability of the dome.

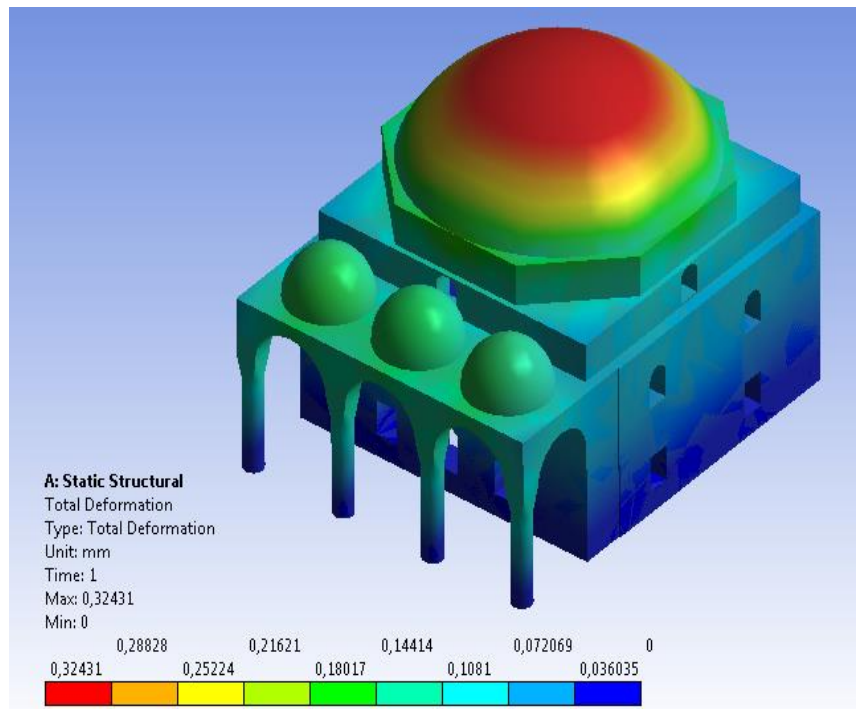

Figure 5. Static Analysis Total Deformation Values.

\section{MODAL ANALYSIS}

Modal analysis provides meaningful insights about the deformation characteristics of a building during an earthquake. The shapes of the free vibrations of the building exhibit the possible areas to undergo deformation in 
detail. As a result of the modal analysis, Figure 6 shows the mode frequency values while Figure 7 shows that the two mode shapes with the highest mass participation ratio are translations on north-south and east-west directions.

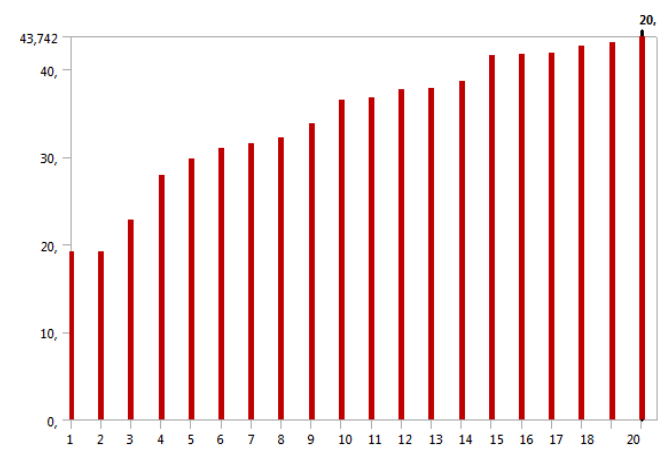

Figure 6. Mode Frequencies.
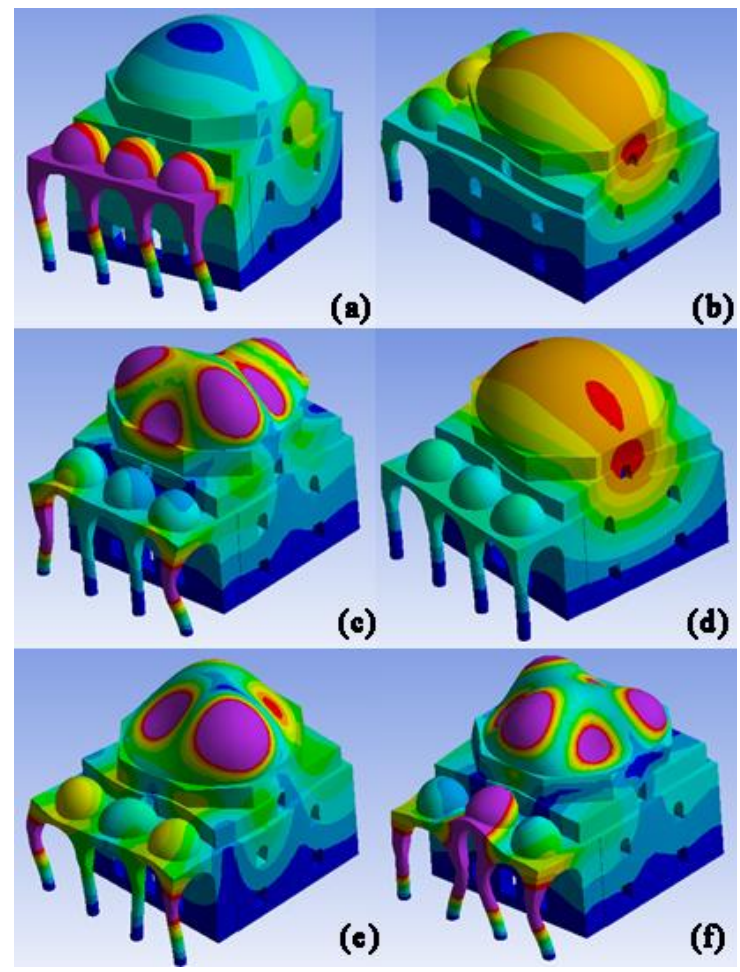

Figure 7. Mode Shapes with The Highest Mass Participation Ratio (A-1. Mode Shape, B-2. Mode Shape, C-4. Mode Shape, D-10. Mode Shape, E-15. Mode Shape, F-20. Mode Shape).

In accordance with these translation shapes, it can be said that the upper part of the mosque above the main outer walls including the dome would be damaged. Moreover, taking other mode shapes into consideration, narthex and main dome participate actively in building's behavior and as a result of stress, the joint points of these parts can undergo deformation. Table 2 shows the active frequency modes, periods, and mass participation ratios. Since the main block is a small-scale building very close to a square plan, the periods remain low. Consequently, this shows that the mosque will resist possible earthquake effects with a rigid structure. 
Table 2. Physical and mechanical features of the materials used in the mosque.

\begin{tabular}{|c|c|c|c|c|c|}
\hline Mode & $\begin{array}{c}\text { Frequency } \\
\text { (hz) }\end{array}$ & $\begin{array}{c}\text { Mass Participation } \\
\text { Ratio (X direction) }\end{array}$ & $\begin{array}{c}\text { Mass Participation } \\
\text { Ratio (Y direction) }\end{array}$ & Mode & $\begin{array}{c}\text { Frequency } \\
\text { (hz) }\end{array}$ \\
\hline 1 & 19.1284 & $0.387504 \mathrm{E}-03$ & 0.801619 & 1 & 19.1284 \\
\hline 2 & 19.2095 & 0.844035 & $3.54 \mathrm{e}-4$ & 2 & 19.2095 \\
\hline
\end{tabular}

\section{LINEAR TIME HISTORY ANALYSIS}

Undoubtedly, earthquakes are the most destructive force acting upon the buildings in our country (M. Karaton (2011), E. Hökelekli (2020) and B.S. Seker (2015)). Therefore, it holds great importance to perform analyses on such buildings with historical and cultural heritage and subsequently to take necessary precautions. Since Merzifon is located on the North Anatolian Fault line which is a first-degree seismic zone, it is expected that an earthquake would cause more damage to such structures. Depending on the intensity, duration, direction and the epicenter of the earthquake, the range and intensity of the damage would vary. In this part of the study, based on the records of Erzincan earthquake in 1992, the analysis of the mosque under earthquake force was performed and possible damage areas were identified. Accelerogram values are given in $\mathrm{mm} / \mathrm{s}^{2}$. Maximum acceleration value for north-south direction is $4049,71 \mathrm{~mm} / \mathrm{s}^{2}$, and $4709,152 \mathrm{~mm} / \mathrm{s}^{2}$ for east-west direction, and the maximum value for vertical direction is $2385,513 \mathrm{~mm} / \mathrm{s}^{2}$. The directions for the acceleration values are chosen in parallel to the directions of the mosque. In other words, the records for north - south direction of the earthquake is applied to north-south direction of the mosque, the east-west direction record to the east-west direction of the mosque, and the vertical direction record is to the vertical direction of the mosque. The accelerogram records of the earthquake are given in Figure 8 (URL-1, 2020) and the directions of the mosque are shown in Figure 9.

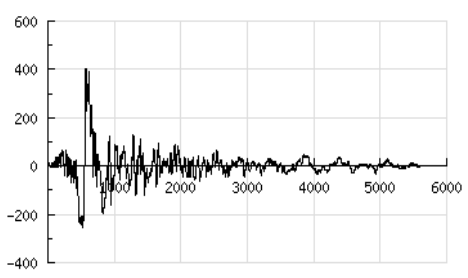

a)

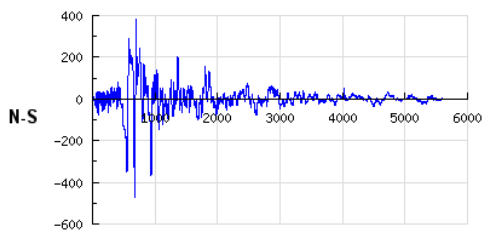

b)

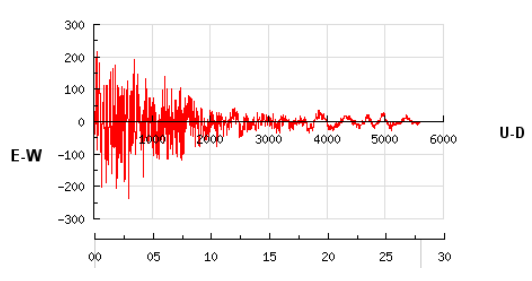

c)

Figure 8. 1992 Erzincan Earthquake. North-South Direction (a), East-West Direction (b), and Up-Down Direction (c). Acceleration Records. 


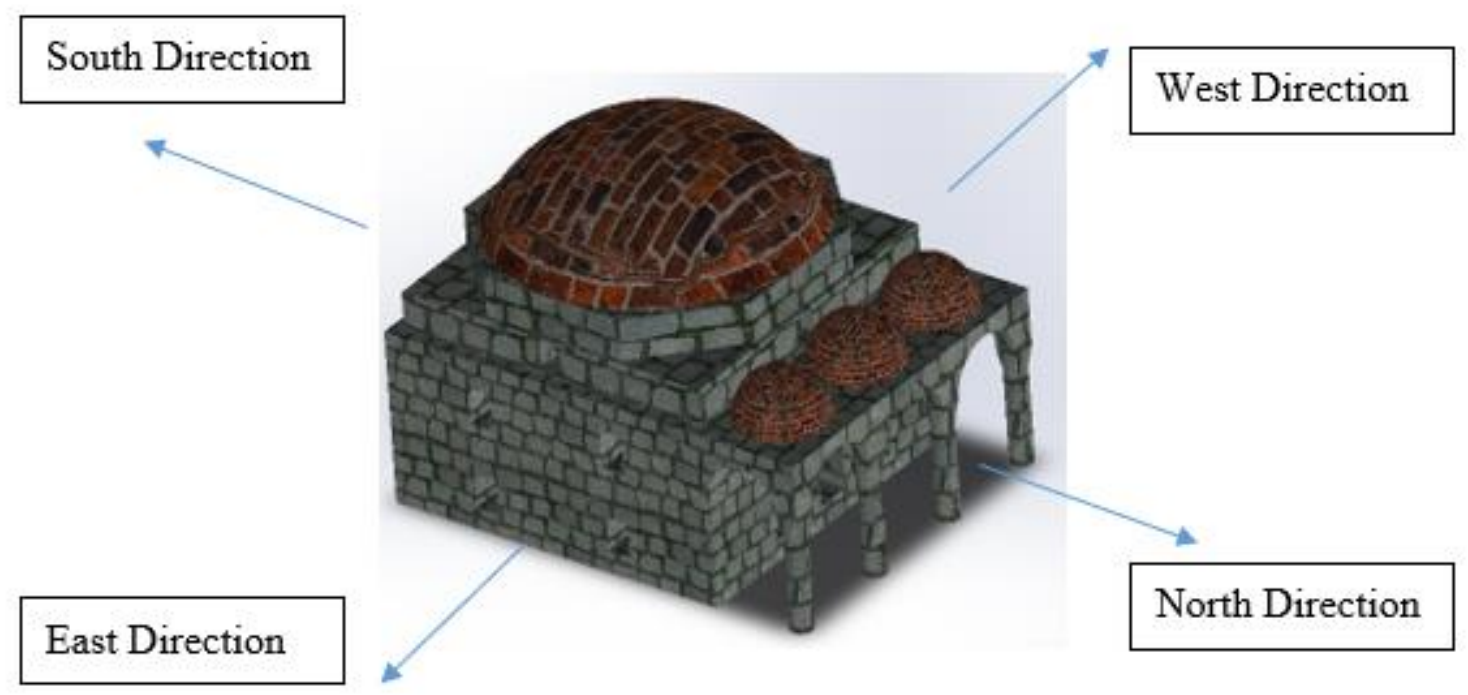

Figure 9. Directions of the Mosque for Time History Analysis.

\section{Linear Time History Analysis of the Mosque Under 1992 Erzincan Earthquake North-South Direction Accelerogram Records}

The principal tensile stress distribution obtained from the analysis can be seen in Figure 10. Maximum values concentrate above and below the window on the upper side of the south front wall. In addition, the top windows located in the same part of the eastern and western front walls exhibit large scale deformations around them and large stress values. Similarly, around the support points of narthex columns and below the entrance front, there are areas with considerable stress concentrations. It can be seen that the maximum value is $0.98 \mathrm{MPa}$ and occurs at the upper part of the south wall.

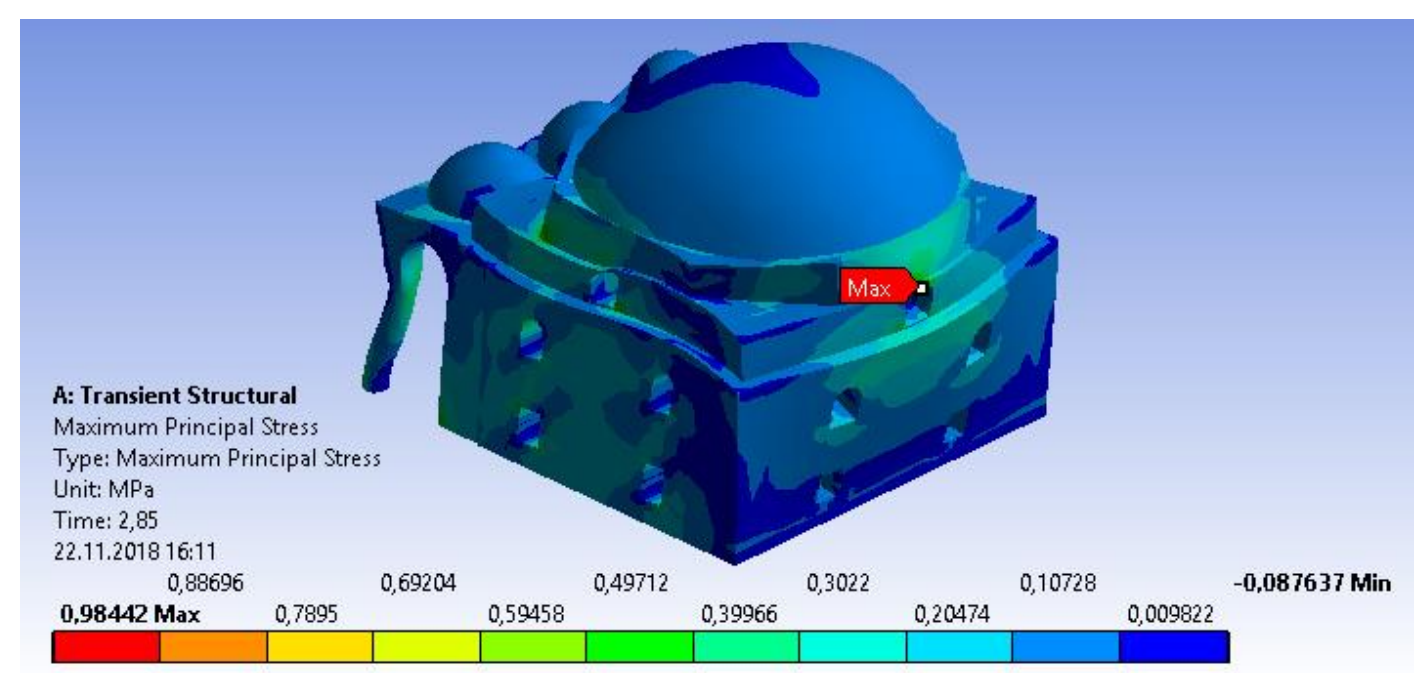




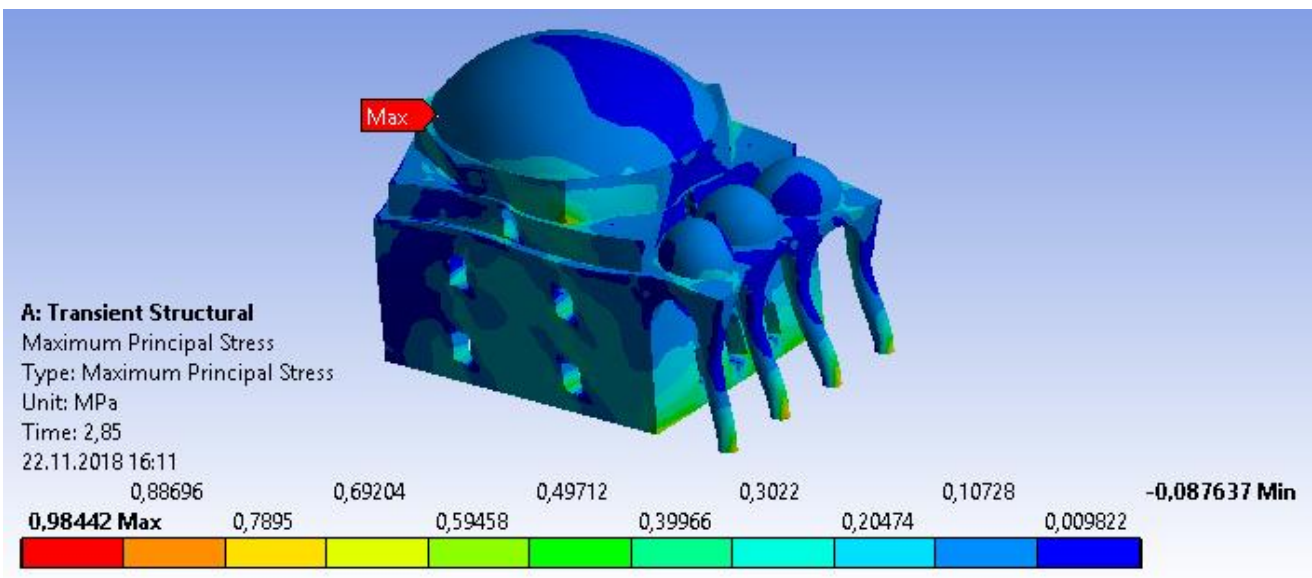

Figure 10. Maximum Principal Stress Distribution.

Figure 11 shows the maximum deformations of the analysis. An examination of these distributions reveals that deformation reaches maximum around top window on southern front during an earthquake. Furthermore, the window at the same height on western and eastern fronts show out of plane deformations. Maximum value is $0,68 \mathrm{~mm}$.

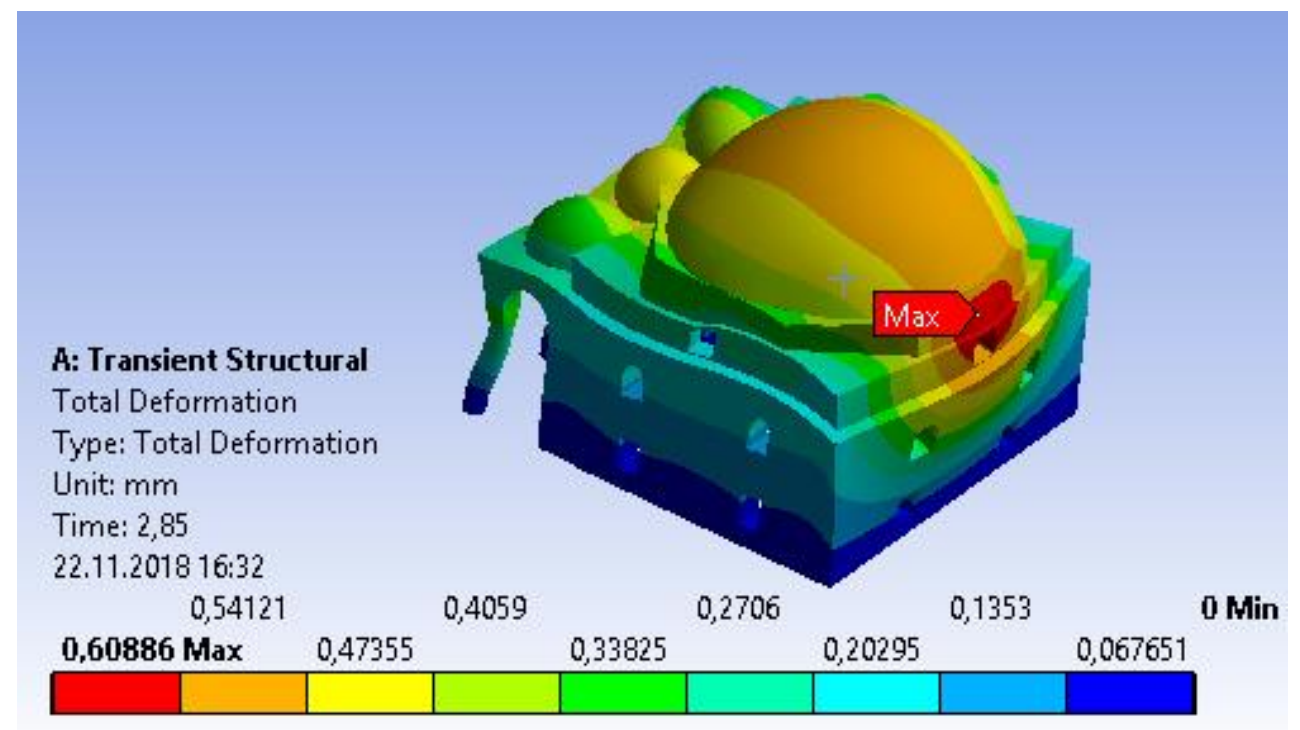

Figure 11. Total Deformation Distribution.

\section{Linear Time History Analysis of the Mosque Under 1992 Erzincan Earthquake East-West Direction Accelerogram Records}

Maximum tensile stress distribution for east-west direction acceleration records analysis can be seen in Figure 12. Examining the figure, we can see that maximum values occur at the upper window on the western front wall which is $0,64 \mathrm{MPa}$. An earthquake in this direction can lead to fractures due to stress concentration at lower parts of the western and eastern front walls. Maximum value is 1,1263 MPa. 


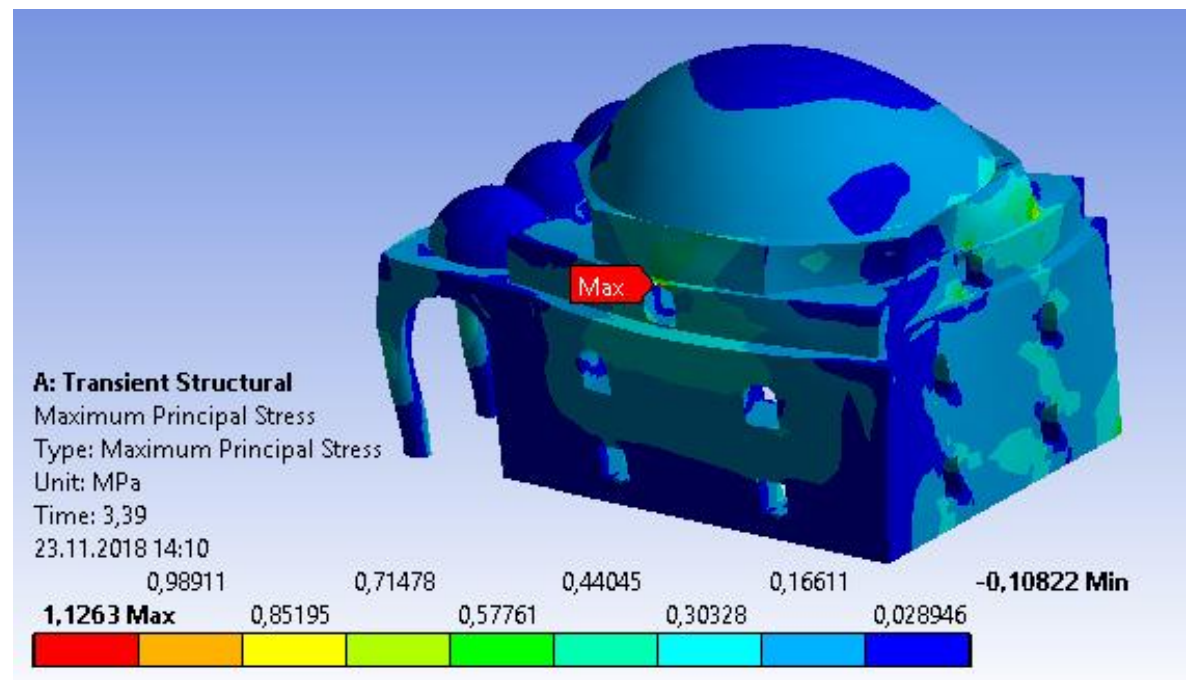

Figure 12. Maximum Principal Stress Distribution.

Maximum deformation values for east-west direction acceleration records are shown in Figure 13. The figure reveals that there is active out of plane behavior from lower windows of the eastern front wall upwards and towards the lower part of the wall. In case of such a deformation, it is predicted that starting from approximately half of the eastern front wall upwards and half of the area between the support points of the dome and its peak point have a chance of collapsing. The maximum value is $0,64 \mathrm{~mm}$.

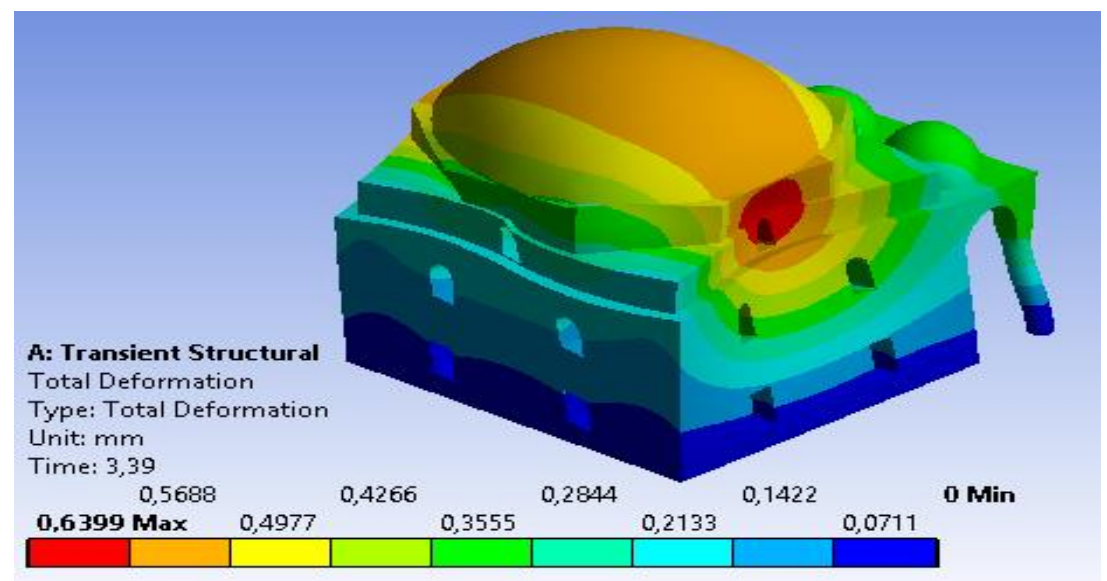

Figure 13. Total Deformation Distribution.

Linear Time History Analysis of the Mosque Under 1992 Erzincan Earthquake Up-Down Direction Accelerogram Records

Figure 14 demonstrates the maximum tensile stress distribution for vertical direction acceleration. This figure clearly shows that the maximum values increase starting from bottom parts of the narthex columns towards joist hangers. In an earthquake in this direction, fractures can occur in columns due to stress concentration in these areas. The maximum value is calculated as $0,168 \mathrm{MPa}$. 


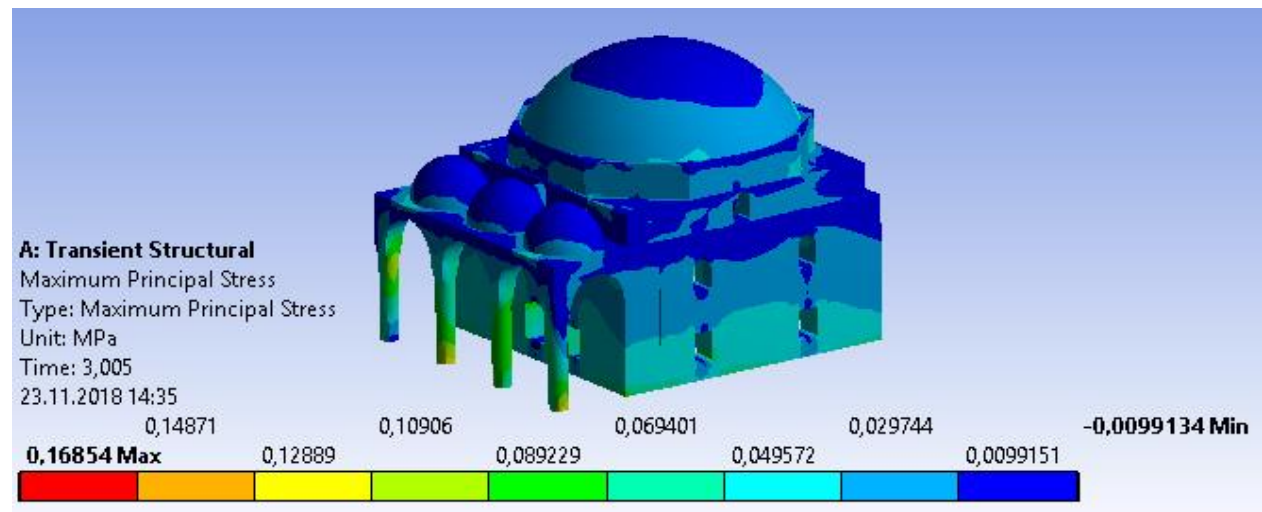

Figure 14. Maximum Principle Stress Distribution.

The deformation values for vertical direction acceleration analysis can be seen in Figure 15. This figure shows that main dome and smaller domes in the narthex have large deformation values. The maximum value is given as $0,047 \mathrm{~mm}$. Deformation values obtained from these analyses are within the limits determined in the regulation (TYDRYK, 2017).

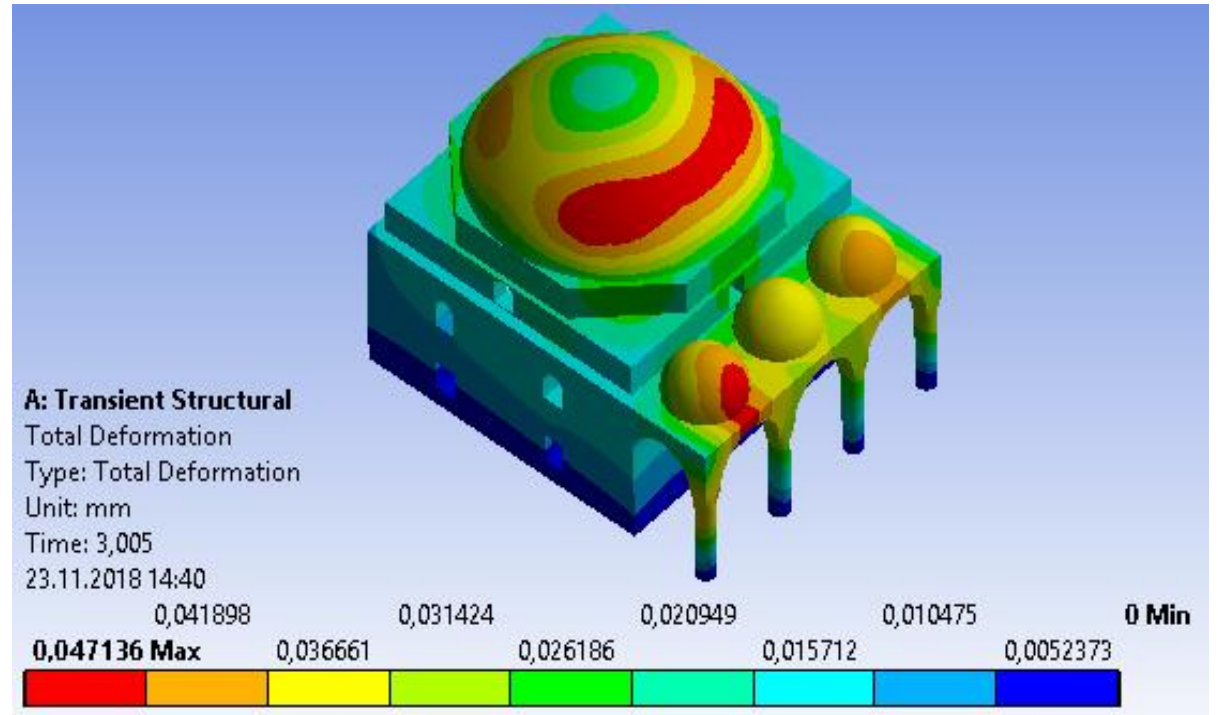

Figure 15. Total Deformation Distribution.

\section{CONCLUSION}

Within the scope of this article, historical Sofular mosque has been subjected to static and dynamic loads. The main objective of the analysis was to identify the parts that can be damaged under these loads. Evaluating all of the analysis results, it is seen that the support points of the main dome stand out as the parts in the most danger under static loads; therefore, special measures need to be taken concerning this part. The horizontal thrust force stemming from the slope of the dome causes to become large stress values on these parts. A possible suggestion could be to surround the dome with either wooden or iron stretchers at these parts. When the deformation values are evaluated 
in this analysis, it can be seen that maximum values are concentrated around the peak point of the dome. This reveals the necessity of ensuring the rigidity of the peak point adequately during construction. In addition, modal analysis reveals that stress concentration points are located in the narthex, main dome and upper parts starting from half of the front walls.

The results of dynamic analysis demonstrate that maximum tensile stress values occur on the eastern wall. Also, narthex part of the mosque participates in the translation motion. These show that in a possible earthquake scenario, deformations could appear at these parts. Furthermore, according to the results of time history analysis, maximum tensile stress and deformation values are concentrated around the windows located on the upper part of the three side walls. It is expected that deformations will occur in two directions along both the upper parts of these windows and the part starting below these windows until the side walls. The values for these two orthogonal directions are obtained as $0,64 \mathrm{~mm}$ and $0,68 \mathrm{~mm}$. The maximum limit for prohibited values in the regulation (TYDRYK, 2017) states that it should be $0.3 \%$ of the building height for immediate use after an earthquake. Since the height of the building is 18 meters, that would render the limit value to be $54 \mathrm{~mm}$ which is quite larger than the obtained values.

Lastly, according to the results of the vertical directional time history analysis, support points of the narthex columns are seen to have the highest values for tensile stresses. Also, main dome has been identified as the riskiest part of the buildings in terms of the deformations. It has to be noted that modal analysis has been quite helpful in determining the dynamic behaviour of the building and identifying the part that experienced deformation and excess stresses.

The parts that are found to be at risk as a result of the analysis are the same parts that were damaged during the 1943 earthquake, which proves the accuracy of the model and the assumptions made. It would be beneficial to conduct non-linear analyses on the stressed parts in order to determine further tensile and deformation forms. It is hoped that the results of this study will be useful for further restoration and renovation projects.

\section{REFERENCES}

ANSYS. (2014). Finite element analysis program. USA.

Aras, F., Krstevka, L., Altay, G. and Tashkov, L. (2011). Experimental and numerical modal analyses of a historical masonary palace. Construction and Building Materials, 25: 81-91.

Aslan, A. and Şahin, A. (2016). Seismic Behaviour Evaluation of Süleymaniye Mosque Under Different Earthquake Records”, Disaster Science and Engineering. Disaster Science and Engineering, 2(2): 67-75.

Asteris, P. G., Chronopoulos, M. P., Chrysostomou, C. Z., Varum, H., Plevris, V., Kyriakides, N. and Silva, V. (2014). Seismic vulnerability assessment of historical masonry structural systems, Engineering Structures. Engineering Structures, 62-63: 118-134.

Bani-Hani, K. and Barakat, S. (2006). Analytical evaluation of repair and strengthening measures of Qasr alBint historical monument—Petra, Jordan. Engineering Structure, 28(10): 1355-1366.

Bayraktar, A. (2006). Tarihi Yapıların Analitik İncelenmesi ve Sismik Güçlendirme Metotları. İstanbul: Beta.

Bayraktar, A., Hökelekli, E., Türker, T., Çalik, İ., Ashour, E. and Mosallam, A. (2019). Window Opening Effects on Structural Behaviour of Historical Masonry Fatih Mosque. International Journal of Architectural Heritage, 13(4): 585-599. doi:10.1080/15583058.2018.1447617

Betti, M. and Vignoli, A. (2011). Numerical assessment of the static and seismic behaviour of the basilica of Santa Maria all'impruneta (Italy). Construction and Building Materials, 25: 4308-4324. doi:10.1016/j.conbuildmat.2010.12.028 
Çerkez, M. (2005). Merzifon'da Türk Devri Mimari Eserleri. (Ph.D.), Ankara University, Ankara.

Gedik, Y. H. and Celep, Z. (2008). Structural Modeling and Seismic Performance Analysis of Mehmet Ağa Mosque in İstanbul. Paper presented at the 8th International Congress on Advances in Civil Engineering, Famagusta, North Cyprus.

Hökelekli, E. (2020). Yapı-Zemin Etkileşiminin Tarihi Yığma Minarelerin Deprem Davranışına Etkisi. DÜMF Mühendislik Dergisi, 11(2):825-38.

Karaton, M. and Aksoy, H. S. (2018). Seismic Damage Assessment of an 891 Years Old Historic Masonry Mosque. Periodica Polytechnica Civil Engineering, 62(1): 126-135.

Lourenço, P. B., Rots, J. G. and Blaauwendraad, J. (1995). Two approaches for the analysis of masonry structures: micro and macro-modeling. HERON, 40(4): 313-340.

Orduña, A., Preciado, A., Galván, F. and Araiza, J. C. (2008). Vulnerability assessment of churches at Colima by 3D limit analysis models. Structural Analysis of Historic Construction: 1297-1302. doi:10.1201/9781439828229.ch149

Paupério, E., Romão, X. and Costa, A. (2012). Seismic Damage To Churches: Observations From The 2011 LKorca (Spain) Earthquake. Paper presented at the 15 WCEE, Lisboa.

Roca, P., Cervera, M., Gariup, G. and Pela, L. (2010). Structural analysis of masonry historical constructions. Arch Computational Methods in Engineering, 17(3): 299-325. doi:10.1007/s11831-010-9046-1

Roca, P., Cervera, M., Gariup, G. and Pela, L. (2010). Structural Analysis of Masonry Historical Constructions. Classical and Advanced Approaches. Archives of Computational Methods in Engineering, 17: 299-325. doi:10.1007/s11831-010-9046-1

Şeker, B. Ş. (2015). Behavioral Assessment of Clock Towers Subsequently Added to Historical Structures. Journal of the Croatian Association of Civil Engineers, 67: 829-841. https://doi.org/10.14256/jce.1169.2014.

Şeker, B. Ş., Çakır, F., Doğangün, A. and Uysal, H. (2014). Investigation of the structural performance of a masonry domed mosque by experimental tests and numerical analysis. Earthquakes and Structures, 6(4): 335350. doi:10.12989/eas.2014.6.4.335

Şeker, B. Ş., Doğangün, A. and Çakır, F. (2013). Merzifonlu Kara Mustafa Paşa Cami Taşıyıcı Sistemi Üzerine İrdeleme. SDU International Technologic Science, 5(1): 112-120.

Toker, S. and Unay, A. İ. (2004). Mathematical Modeling and Finite Element Analysis of Masonry Arch Bridges. Gazi University Journal of Science, 17(2): 129-139.

TYDRYK. (2017). Tarihi Yapılar İçin Deprem Risklerinin Yönetimi Kılavuzu. Ankara, Turkey: General Directorate of Foundation.

URL-1. (2020). Retrieved from http://kyhdata.deprem.gov.tr/2K/genAcc.php?dst=TU9EVUxFX05BTUU9ZXZ0RmlsZSZNT0RVTEVfVE FTSz1zaG93Jk1PRFVMRV9TVUJUQVNLPUFMTCZNT0RVTEVfVEFSR0VUPW9sZCZUQVJHRVQ9 MTk5MjAzMTMxNzE4MzlfMjQwMiZUQVJHRVRfU0VSSUFMPTI5 